\title{
Sistem Informasi Penjadwalan Rapat Kerja Pada Perumdam Tirta Kerta Raharja Kabupaten Tangerang
}

\author{
Bayu pramono*1, Ayu Fadhilah Tiara Anggun W2 ${ }^{2}$ Lina Yasyfa ${ }^{3}$ \\ ${ }^{1,2,3}$ Program Studi Sistem Informasi Universitas Raharja \\ e-mail: *1 bayupramono@raharja.info, ${ }^{2}$ ayu.fadhilah@raharja.info, ${ }^{3}$ lina.yasyfa@raharja.info
}

\begin{abstract}
Abstrak
Perumdam Tirta Kerta Raharja Kabupaten tangerang merupakan sebuah perusahaan air minum daerah yang dimiliki pemerintah kabupaten tangerang, yang bergerak di bidang Air Bersih. Penjadwalan ruang rapat pada Perumdam Tirta Kerta Raharja Kabupaten Tangerang tersendiri masih menggunakan form undangan dan nota dinas pada saat pengajuan, sehingga unit kerja harus bertemu langsung dengan bagian rumah tangga untuk menyerahkan form tersebut. Tujuan penelitian merupakan Sistem yang masih tergolong rumit dan tidak efektif dikarenakan membutuhkan waktu lama untuk berkoordinasi dengan bagian rumah tangga secara langsung sedangkan jika tidak melakukan koordinasi tersebut akan terjadinya jadwal bentrok. Maka untuk mengatasi hal tersebut dibutuhkannya sistem penjadwalan yang terkomputerisasi dengan baik agar kinerja tersebut lebih efektif dan efisien sehingga tidak terjadinya jadwal bentrok. Hasil mengenai penelitian dini merupakan website mengenai Penjadwalan ruang rapat secara terdatabase atau berbasis web dapat memudahkan Rumah tangga dalam mengontrol penjadwalan dan Unit kerja dalam melaksanakan rapat. Sehingga dengan sistem digital diharapkan mampu memudahkan alur penjadwalan ruang rapat.
\end{abstract}

Kata Kunci: Penjadwalan ruang rapat kerja, Koordinasi, dan Komputerisasi.

\begin{abstract}
Perumdam Tirta Kerta Raharja Tangerang Regency is a regional drinking water company owned by the Tangerang Regency government, which is engaged in the Clean Water sector. The scheduling of meeting rooms at Perumdam Tirta Kerta Raharja Tangerang Regency itself still uses the invitation form and official notes at the time of submission, so the work unit must meet directly with the household section to submit the form. The research objective is a system that is still classified as complicated and ineffective because it takes a long time to coordinate with the household directly, whereas if it does not coordinate, there will be a conflicting schedule. So to overcome this, a well-computerized scheduling system is needed so that the performance is more effective and efficient so that there are no conflicting schedules. The result of early research is a website regarding scheduling of meeting rooms in a database or web-based manner which can facilitate households in controlling scheduling and work units in conducting meetings. So that the digital system is expected to facilitate the flow of meeting room scheduling.
\end{abstract}

Keywords : Meeting room scheduling, coordination, and computerization. 


\section{PENDAHULUAN}

Semakin bertambahnya zaman mempengaruhi perubahan cara pandang dan hidup lingkungan sekitarnya. Teknologi informasi adalah 2 hal yang sangat penting perannya dalam menunjang kehidupan kita semua tanpa kita sadari. Semakin majunya suatu negara tidak lepas dari penggunaan masyarakatnya yang bergantung pada teknologi dan informasi.

Perusahaan Air Minum Daerah Tirta Kerta Raharja Kabupaten Tangerang (PERUMDAM TKR) merupakan suatu perusahaan air minum yang dimiliki oleh Pemerintah Kabupaten Tangerang. PERUMDAM Tirta Kerta Raharja Kabupaten Tangerang dibangun oleh Pemerintah Kabupaten Tangerang pada tanggal 13 April 1976. PERUMDAM Tirta Kerta Raharja Kabupaten Tangerang memiliki tugas dan tanggung jawab sebagai penyedia air minum untuk warga Kabupaten Tangerang dan sekitarnya. Dengan meningkatkan kinerjanya, dibutuhkan penunjang yang membuat perusahaan ini tak ketinggalan dengan perusahaan lain yaitu dengan menigkatkan sarana teknologi komunikasi dan informasi. Untuk meningkatkan kinerja tersebut PERUMDAM Tirta Kerta Raharja Kabupaten Tangerang membutuhkan beberapa media komunikasi yang dapat memudahkan pekerjaannya melalui internet, salah satunya yaitu menggunakan website.

Masalah yang dihadapi oleh PERUMDAM Tirta Kerta Raharja Kabupaten Tangerang adalah proses penjadwalan ruang rapat. Pada proses penjadwalan ruang rapat memakan waktu yang cukup lama dan permasalahan ini sering terjadi dikarenakan sistem belum terkelola dengan baik. Dari mulai tahap permohonan peminjaman ruang rapat masih menggunakan form berupa kertas hingga tahap laporan nota dinas berupa hasil dokumen, sehingga memerlukan banyak kertas pada proses penjadwalan ruang rapat. Dalam proses tersebut masih kurang monitoring sehingga rumah tangga harus melakukan pengecekan ke ruangan terkait apakah jadwal tersedia atau tidak dan dapat mengakibatkan jadwal bentrok apabila rumah tangga tidak melakukan pengecekan ruangan terlebih dahulu serta mengonfirmasikan ke unit kerja terkait.

Dengan menghadapi permasalahan-permasalahan yang sering terjadi, penulis menyimpulkan bahwa penjadwalan ruang rapat pada PERUMDAM Tirta Kerta Raharja harus menggunakan sistem yang terkomputerisasi dengan menggunakan database, yang dapat mengontrol jadwal dan kebutuhan-kebutuhan saat sebelum dan sesudah rapat berlangsung. Dengan adanya sistem penjadwalan ruang rapat yang sudah terkomputerisasi berbasis web dapat memudahkan segala kegiatan penjadwalan ruang rapat dan terhindar dari masalah yang sering terjadi. Penjadwalan adalah penentuan waktu dan urutan operasi dalam proyek dan perakitan mereka untuk memberikan waktu penyelesaian keseluruhan. Seperti yang disebutkan sebelumnya, penjadwalan berfokus pada satu bagian dari upaya perencanaan. ${ }^{[1]}$

Definisi rapat pada Kamus Besar Bahasa Indonesia ialah perkumpulan (pertemuan) guna membahas suatu sidang, majelis. Peneliti memfokuskan rapat untuk kegiatan yang berguna pada penelitian sistem monitoring penjadwalan ini. ${ }^{[2]}$

Pendapat Annisa dan Kustiyahningsih yang dikutip oleh Jayanti dan Nugroho pada Jurnal Saintekom Vol.7 No.2 (2017), web ialah layanan yang didapat oleh pengguna komputer yang tersambung ke jaringan internet. ${ }^{[3]}$

\section{PERMASALAHAN}

Masalah yang dihadapi pada sistem yang digunakan ialah :

1. Pada proses penjadwalan ruang rapat memakan waktu cukup lama dan permasalahan ini sering terjadi dikarenakan sistem yang belum terkelola dengan baik. Dari mulai tahap permohonan peminjaman ruang rapat masih menggunakan form berupa kertas hingga tahap 
laporan nota dinas berupa hasil dokumen, sehingga memerlukan banyak kertas pada proses penjadwalan ruang rapat.

\section{Metode PENELITIAN}

Pada penelitian yang dilakukan, peneliti melakukan beberapa tahapan penelititian diantaranya :

\section{Metode Pengumpulan Data}

Dengan metode ini informasi yang digunakan peneliti, yaitu:

\section{Observasi}

Peneliti melakukan pegamatan secara langsung pada PERUMDAM Tirta Kerta Raharja dan mempelajari permasalahan yang ada, mengamati data-data dan permasalahan yang sedang terjadi.

\section{Wawancara}

Metode dilakukan berdasarkan wawancara langsung oleh peneliti kepada unit kerja bagian Sistem Informasi Manaejemen PERUMDAM Tirta Kerta Raharja untuk mengumpulkan data mengenai sistem jadwal ruang rapat yang sedang berjalan, serta sistem yang diharapkan agar pengelolaan jadwal ruang rapat berlangsung secara efisien.

\section{Studi Pustaka}

Litteratur review atau biasa di sebut studi pustaka dilakukan dengan cara mengumpulkan data menggunakan berkas, seperti photo, gambar, ataupun dokumen elektrornik yang mampu meningkatkan hasil penelitian yang efektif. Studi pustaka memengaruhi kredibilitas hasil penelitian yang dilakukan.

\section{Metode Analisis}

Dengan Metode Analisis pada penelitian ini digunakan metode PIECES (Performance, Information, Economics, Control, Efficiency, Service) yang diharapkan peneliti agar medapatkan inti masalah yang akurat. Dengan menggunakan metode PIECES, menggunakan aspek penelitian yaitu, Kinerja sistem, Informasi, Ekonomi, Pengendalian, Efisiensi, juga Pelayanan. Tujuan peneliti menggunakan metode ini agar mendapatkan permasalahan inti yang di cari dari hasil penelitian tersebut guna memperoleh sistem baru yang lebih terkontrol pada pengelolan Jadwal Ruang Rapat PERUMDAM Tirta Kerta Raharja.

\section{Literature review} dibahas:

penelitian yang telah dilakukan dan memiliki hubungan dengan penelitian yang

1. Penelitian yang dilakukan oleh Nanda Tiara Bestari dalam Jurnal Manajemen Informatika (2020) yang berjudul, "Rancang Bangun Aplikasi Agenda Rapat Berbasis Android" Penelitian ini memiliki permasalahan pada proses pembuatan agenda rapat yang masih menggunakan surat undangan untuk diberikan kepada yang bersangkutan atau dengan mendatangi secara langsung, melalui grup chatting atau broadcast. Begitu juga dengan informasi mengenai rapat yang masih dilakukan secara manual sehingga memakan waktu dan tidak efektif. Peneliti memberikan solusi alternatif untuk pemecahan masalah di atas, yaitu dengan menggunakan aplikasi agenda rapat yang dapat membantu proses pembuatan agenda rapat. Aplikasi ini dibuat dengan metode waterfall. Metode ini memiliki penerapan yang berurutan, dimulai dengan tahap analisis, desain, implementasi sistem, pengujian dan pemeliharaan. Aplikasi ini juga telah diuji menggunakan metode pengujian Black Box Testing. ${ }^{[4]}$

2. Penelitian yang dilakukan oleh Saman Alfarisi yang berjudul, "Sistem Informasi Penjadwalan Kegiatan Belajar Mengajar Pada Mi Al-Falah Berbasis Android.” Dalam 
Jurnal Prosiding Semnastek (2018). Tujuan penelitian ini ialah membuat sistem informasi penjadwalan kegiatan belajar mengajar berbasis android guna mempermudah administrator sekolah dalam menysun jadwal kegiatan belajar. Peneliti memberikan masukan dengan menggunakan aplikasi berbasis android supaya dapat mempermudah penjadwalan mata pelajaran secara lebih teratur, lancar dan mudah di akses oleh administrator. ${ }^{[5]}$

3. Penelitian yang dilakukan oleh Anisa Melinda Rahmayunita (2019) yang berjudul, "Sistem Informasi Ruang Rapat (Siamir) di PT Pertamina Geothermal Energy Wilayah Kamojang." Penelitian ini berisi tentang permasalahan yang terjadi pada cara meminjam ruangan untuk rapat kerja di PT Pertamina Geothermal Energy Wilayah Kamojang masih menggunakan sistem pembukuan yang sering kali terdapat masalah pada proses meminjam ruangan rapat. Oleh karena itu peneliti memberikan solusi dalam pemecahan masalah dengan membangun sistem informasi ruangan meeting adalah sistem berbasis website. Aplikasi ini memudahkan pekerja dalam menjalankan proses meminjam ruangan rapat. Program disini dibangun menggunakan Prototype. ${ }^{[6]}$

4. Penelitian yang dilakukan oleh Egia Rosi Shubiyakto dan Yani Parti Astuti yang berjudul, "Pengembangan Aplikasi Penjadwalan Rapat Menggunakan Metode Phased Development." Pada Jurnal Ilmiah Dinamika (2019). Penelitian ini berisi tentang permasalahan yang terjadi dalam pengaturan agenda rapat. Pengaturan agenda rapat yang masih dilakukan menggunakan buku memo dapat meningkatkan resiko kehilangan dokumen baik karena keteledoran atau bencana alam. Peneliti menggambarkan solusi permasalahan dengan membangun aplikasi penjadwalan rapat menggunakan metode pengembangan sistem yaitu metode Phased Development. Metode ini terdiri dari beberapa tahapan yakni perencanaan, analisis, perancangan, implementasi lalu menghasilkan versi aplikasi. Metode yang dibuat menghasilkan versi aplikasi yang memiliki series. Keunggulan dari metode ini adalah menghasilkan sistem yang berguna bagi pengguna secara cepat dan banyak fungsi penting yang diuji dengan lebih baik. Peneliti juga menggunakan alat bantu dalam proses penelitian ini dengan menggunakan bahasa pemrograman PHP dan basis data MySQL. ${ }^{[7]}$

5. Penelitian yang dilakukan oleh Wresni Anggraini dan Febri Novia Warman (2019) dalam jurnal EMACS (Engineering, Mathematics and Computer Science) yang berjudul, "Perbaikan Berkelanjutan Pada Sistem Penjadwalan Perkuliahan dengan Penjadwalan Berbasis Aplikasi dan Website." Penelitian ini bertujuan untuk memecahkan masalah dalam penjadwalan perkuliahan yang dibuat secara manual yang dibuat secara manual membutuhkan waktu yang lama dan harus dibuat secara berulang-ulang karena banyak kendala, seperti jumlah mata kuliah, jumlah dosen, jumlah ruangan, jumlah mahasiswa yang harus dipertimbangkan. Maka peneliti melakukan pemecahan masalah dengan merancang sistem informasi penjadwalan berbasis website dan android di Teknik Industri Universitas Islam Negri Sultan Syarif Kasim Riau. Penelitian ini juga mengukur tingkat keberhasilan sistem menggunakan User Acceptance Testing (UAT) ${ }^{[8]}$

6. Penelitian yang dilakukan oleh Mohammad Al-Haj Hassan dan Osama Al Haj-Hassan (2016) dengan judul "Constraint Aware and User Friendly Exam Scheduling System" Penelitian yang dibuat meggunakan system penjadwalan grafik Teknik. Peneliti focus pada dua aspek yang menjadi dasar dalam penelitian ini, yaitu kedala yang dihadapi oleh system dan penggunaan user Friendly Interface dari system. ${ }^{[9]}$

7. Penelitian yang dilakukan oleh Venkat Rohini dan A.M Natarajan (2016) dengan judul "Comparism of Genetic Algorithm with particle Swarm Optimisation, Ant Colony Optimisation and Tabu Search Based on University Course Scheduling System" Penelitian ini berdasar tentang perencanaan metode yang sesuai untuk memecahkan masalah penjadwalan mata kuliah universitas. Makalah ini membandingkan penggunaan Particle Swarm Optimization (PSO), Ant Colony Optimization (ACO), Tabu Search and Genetic Algorithm (GA) dalam persiapan sistem penjadwalan mata kuliah universitas. permasalahan yang harus terpenuhi dan beberapa kendala batasan yang harus dipenuhi dan 
dipertimbangkan. Algoritma harus memeriksa kepuasan dari batasan keras dan kemungkinan untuk memenuhi batasan lunak. ${ }^{[10]}$

\section{HASIL DAN PEMBAHASAN}

Pada penelitian tersebut, akan dibahas perihal pembuatan sistem informasi penjadwalan ruang rapat pada Perumdam Tirta Kerta Raharja Kabupaten Tangerang. Pada penelitian yang dilakukan, peneliti mengusulkan sistem usulan yang mampu mengelola penjadwalan ruang rapat. Guna melaksanakan riset pada masalah yang ada, juga tidak melenceng dari masalah yang dibahas, peneloti berfokus pada bagaimana mengelola penjadwalan untuk ruang rapat pada Perumdam Tirta Kerta Raharja Kabupaten Tangerang .

\section{Analisis PIECES}

1. Kinerja Sistem (Performance)

Prosedure penjadwalan ruang rapat pada PERUMDAM Tirta Kerta Raharja masih manual. dikarenakan pada saat proses pengajuan form undangan dan nota dinas masih menggunakan kertas sehingga kurang efektif dan efisien.

2. Informasi (Information)

Rumah Tangga mengalami banyak kendala pada saat penjadwalan ruang rapat dikarenakan informasi yang ada kurang efektif sehingga proses pengaturan memerlukan waktu yang cukup lama dalam mengatur jadwal yang bentrok.

3. Ekonomi (Economy)

Pada proses ini masih menggunakan lembaran kertas yang berupa form undangan dan Nota dinas yang masih menjadi acuan untuk mengatur jadwal dari Unit kerja ke bagian Rumah tangga. Kegiatan tersebut masih berjalan hingga saat ini dan banyak kendala yang mnyebabkan sistem ini membuang banyak waktu.

4. Keamanan (Control)

Pengaturan yang masih kurang efektif dikarenakan banyaknya pemintaan jadwal rapat yang melebihi persediaan ruangan sehingga pengaturan yang masih manual akan memakan waktu cukup lama dan tidak efisien. Sehingga pengaturan ini menyebabkan jadwal yang bentrok.

5. Efesiensi (Efeciency)

Di butuhkan waktu yang cukup lama pada proses penjadwalan, sehingga rumah tangga harus mengecek kembali jadwal yang sudah terkonfirmasi lewat form undangan dan Nota dinas. Pada saat pengaturan jadwal jika terjadi bentrok maka unit kerja harus melakukan penjadwalan ruang sehingga pada sistem ini mengakibatkan kurang efektif dan efisien.

6. Layanan(Service)

Pada proses yang berjalan hasil rekapan laporan jadwal rapat masih menggunakan buku besar sehingga banyak tumpukan dalam pengarsipan dan pada saat pencaharian membutuhkan waktu yang relative lama. Sehingga sistem ini kurang efektif.

\section{UseCase Diagram}

UseCase Diagram yang digambarkan sistem informasi penjadwalan ruang rapat yang berjalan digambarkan alur sistem dengan Use case dan melibatkan aktor. Mengenai diagram dibawah, ada 3 aktor yang dapat menjalanlan pekerjaan pada sistem, ialah Unit kerja, Rumah tangga, Direktur. Juga terdapat 11 (sebelah) UseCase yang dapat dijalankan aktor yang disebutkan. 


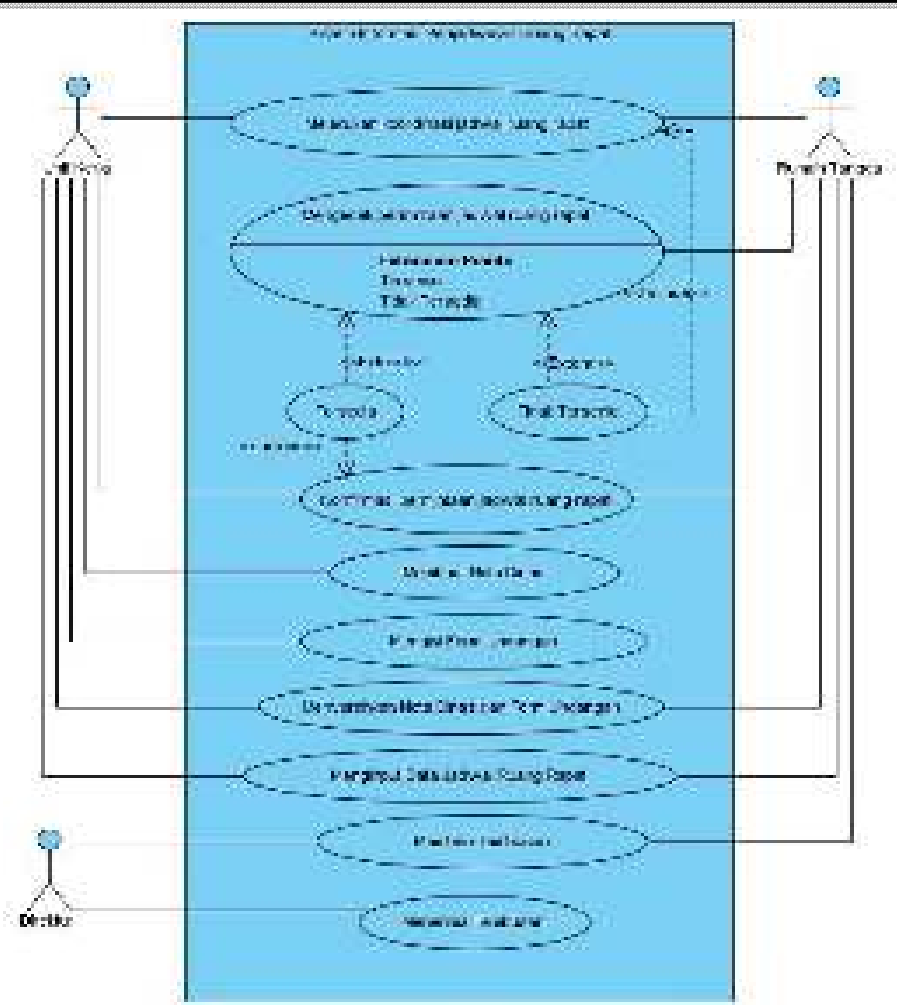

Gambar 1. Use Case Sistem Informasi penjadwalan ruang rapat

\section{RANCANGAN SISTEM}

Dengan mengatasi masalah yang sering terjadi, maka peneliti mengusulakn untuk membuat sistem guna penjadwalan ruang rapat berbasis web. Dengan begitu, informasi perihal jadwal rapat lebih efektif dan efisien.

\section{Use Case Diagram}

Berikut yaitu UseCase Diagram dirancangan oleh website penjadwalan ruang rapat yang mejelaskan proses sistem yaitu :

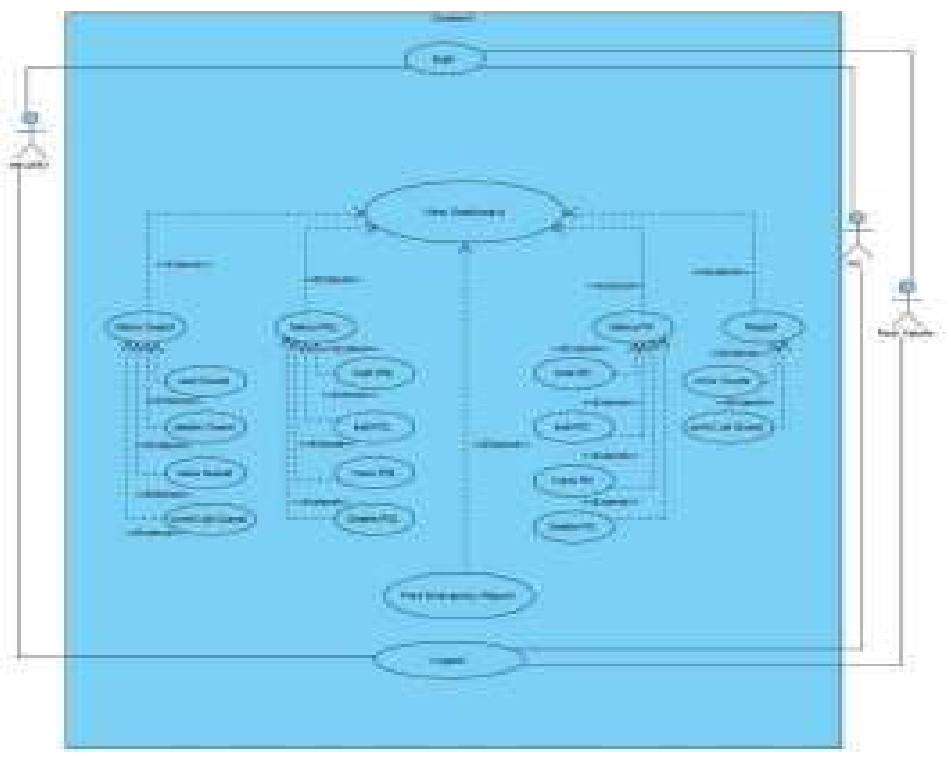

Gambar 2. Use Case rancangan Sistem Informasi e-guest book 
Berdasarkan gambar, memiliki 1(satu) sistem mencakup semua proses yang dilakukan, (tiga) aktor yang dilakukan pada proses yang diusulkan yaitu User, Rumah Tangga, \& Direktur.dan enam usecase yang akan dijalankan oleh aktor yang disebutkan.

\section{Class Diagram}

Classdiagram (diagram kelas) yang mempermudah menjabarkan field pada sistem yang disusulkan. Berikut diagram kelas Sistem Informasi penjadwalan ruang rapat berbasis website:

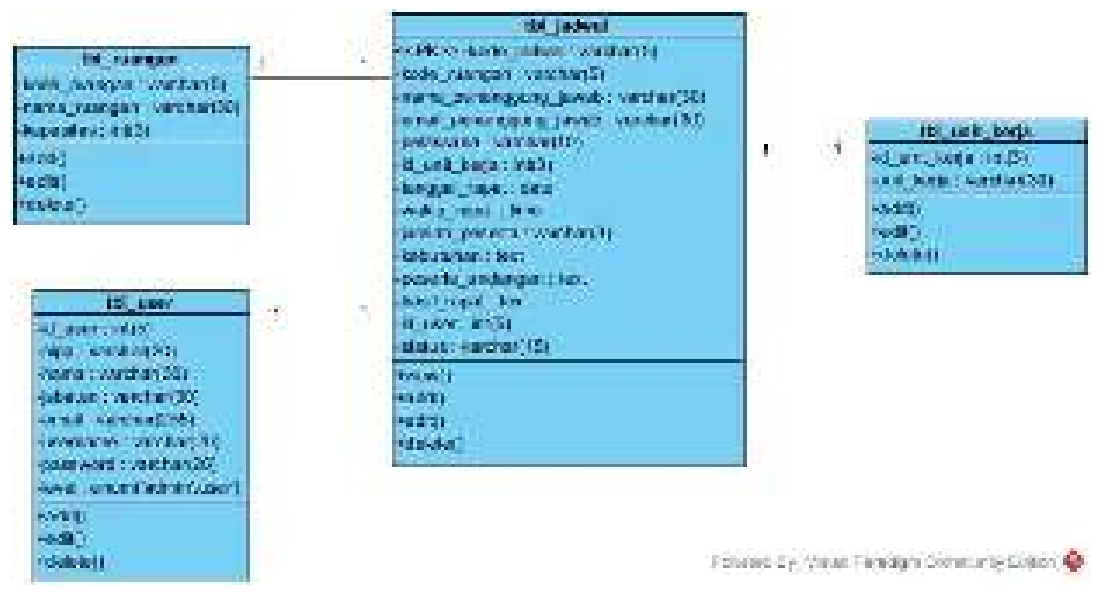

Gambar 3. Class Diagram penjadwalan ruang rapat

Kelas Diagram Rancangan Sistem Informasi penjadwalan ruang rapat menjabarkan rancangan basis data yang dibutuhkan pada sistem ini.

\section{Tampilan Rancangan Sistem Informasi}

Berikut ini tampilan penjadwalan ruang rapat berbasis web:

1. Tampilan Menu Login

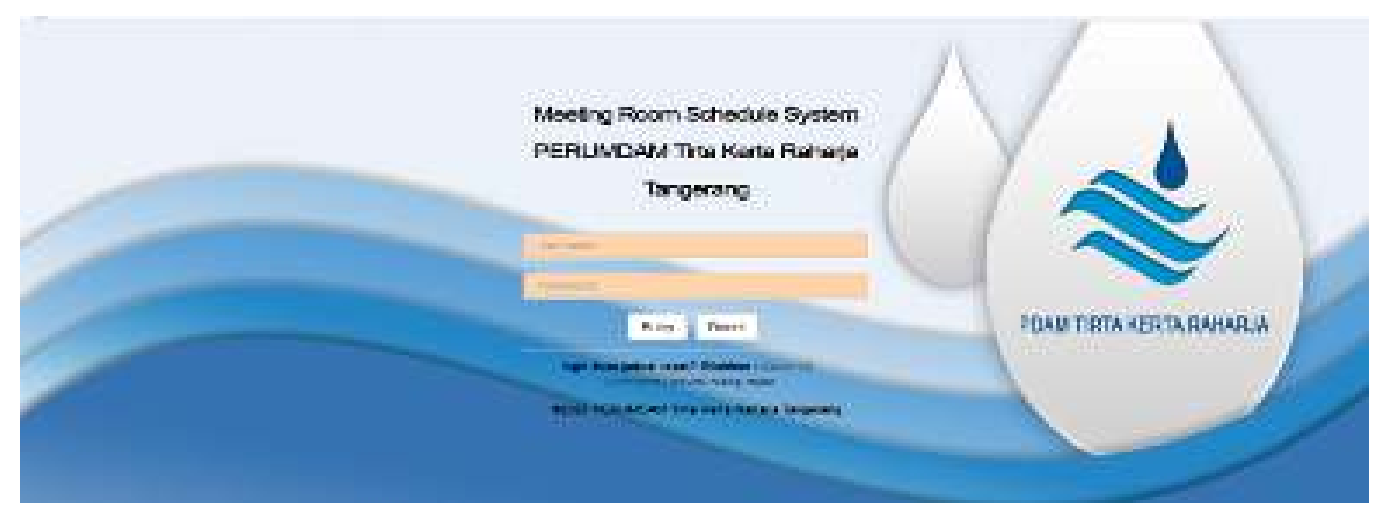

Gambar 4. Tampilan menu login

Pada halaman login adalah halaman yang digunakan ketika user ingin memasuki halaman website 
2. Tampilan Menu Registrasi

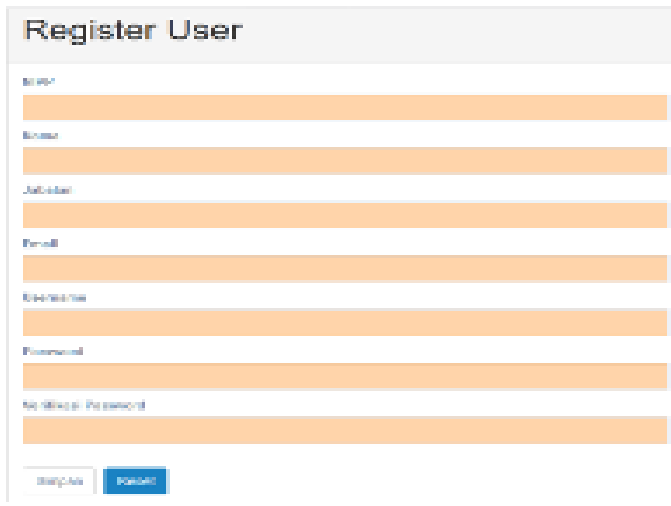

Gambar 5. Tampilan menu registrasi

Pada halaman menu registrasi dapat digunakan ketika user ingin melakukan registrasi.

3. Tampilan Menu Home

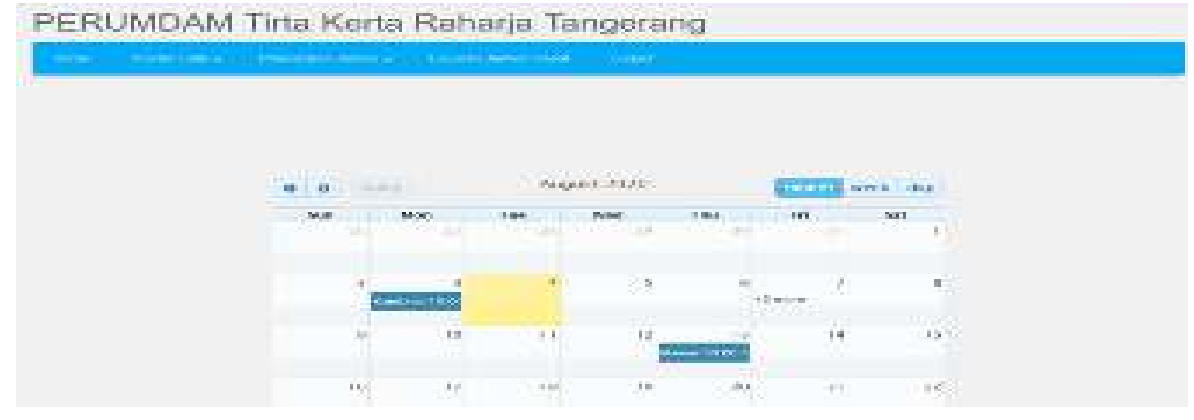

Gambar 6. Tampilan menu home

Pada halaman home berisi informasi mengenai ruang dan tanggal yang ingin digunakan oleh karyawan PERUMDAM Tirta Kerta Raharja.

4. Tampilan Menu Master Data

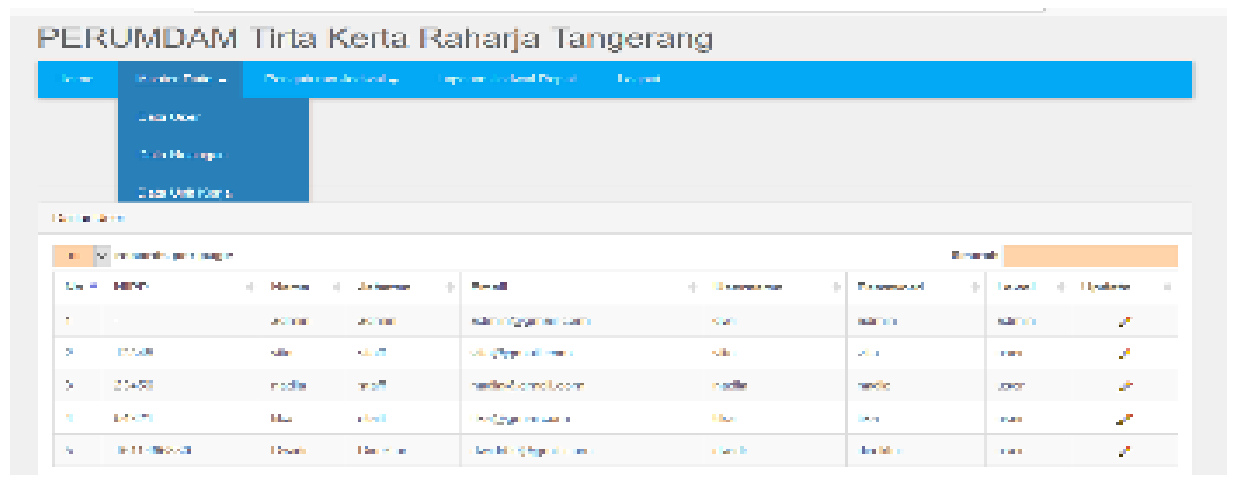

Gambar 7. Tampilan menu master data

Pada halaman ini digunakan oleh user untuk menambahkan dan menampilkan menu master data.

5. Tampilan Menu Pengaturan Jadwal 


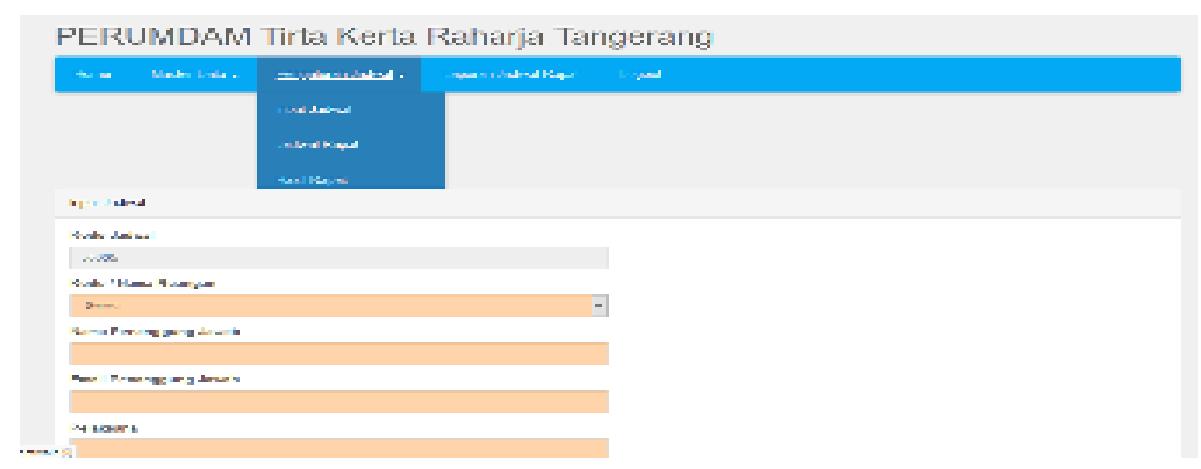

Gambar 7. Tampilan menu pengaturan jadwal

Pada halaman ini digunakan untuk melakukan pengaturan jadwal ruang rapat.

6. Tampilan Menu Laporan Jadwal Rapat

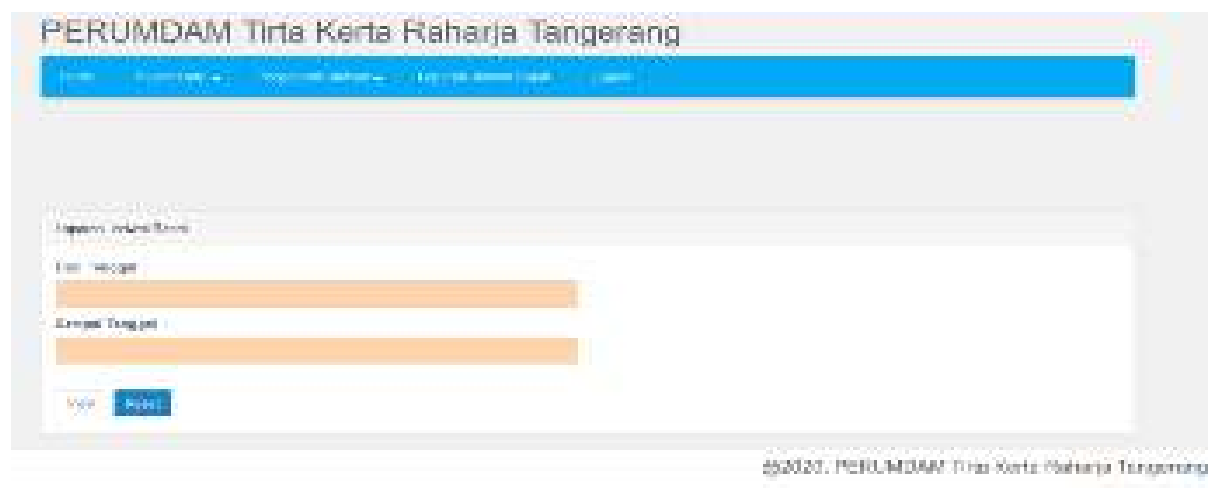

Gambar 8. Tampilan menu laporan jadwal rapat

Pada halaman ini terdapat laporan mengenai jadwal ruang rapat yang sudah digunakan oleh para karyawan.

\section{KESIMPULAN}

Berdasarkan kesimpulan yang diambil peneliti dalam melakukan penelitian yang dibuat pada PERUMDAM Tirta Kerta Raharja penulis mengambil kesimpulan sebagai berikut : Proses penjadwalan ruang rapat pada PERUMDAM Tirta Kerta Raharja Kabupaten Tangerang masih secara manual dengan menggunakan form undangan dan Nota Dinas untuk pengajuan. Unit kerja melakukan koordinasi kepada bagian rumah tangga lalu setelah itu bagian rumah tangga akan mengecek jadwal ruang rapat yang tersedia, jika tidak tersedia maka melakukan pengajuan ulang tetapi jika tersedia bagian rumah tangga akan mengkonfirmasi saat koordinasi pengajuan penjadwalan ruang rapat berlangsung. Jika sudah terkonfirmasi, unit kerja akan mengisi form undangan dan nota dinas sebagai syarat lalu akan di konfirmasi oleh bagian rumah tangga dan unit kerja bisa menggunakan ruang rapat sesuai dengan jadwal yang di telah dibuat. Penjadwalan Ruang Rapat pada saat ini pengaturannya kurang efisien, dikarenakan proses pengajuannya yang memakan banyak waktu dan tidak terkontrol dengan baik. Maka dengan adanya sistem yang telah dibuat ini diharapkan dapat memudahkan pekerjaan bagian rumah tangga dalam mengatur dan menginput penjadwalan ruang rapat yang akan digunakan oleh unit kerja. Dalam meminimilasir terjadinya penjadwalan ulang yang memakan waktu banyak maka dibutuhkan sistem yang telah terkomputerisasi berbasis web agar penjadwalannya lebih cepat 
dan mudah dalam menginput, mengatur dan mecari data jadwal ruang rapat pada PERUMMDAM Tirta Kerta Raharja. Dalam merancang sistem penjadwalan ruang rapat supaya dapat digunakan dengan lebih efektif dan efisien maka peneliti menggunakan sistem yang dapat mengupdate secara berkala dan dapat memudahkan saat melakukan pencarian data. Untuk itu rumah tangga dapat mengatur data yang sudah terinput secara mudah, cepat dengan menggunakan sistem penjadwalan ruang rapat.

\section{SARAN}

Setelah melakukan analisis pada PERUMDAM Tirta Kerta Raharja, peneliti mempunyai beberapa saran yang akan disampaikan kepada stakeholder. Berikut adalah beberapa saran yang bisa menjadi acuan adalah sebagai berikut : Sistem yang terkomputerisasi berbasis web akan mengatur jadwal rapat dengan lebih efisien dan lebih terupdate, sehingga masalah-masalah yang sering dihadapi akan diatasi dengan mudah. Sistem yang memudahkan penjadwalan ruang rapat dan terkomputerisasi dengan berbasis web, maka perlu diadakannya pelatihan bagi Unit Kerja, Rumah Tangga, dan Direktur Utama agar yang terlibat dapat memahami dalam peggunaan sistem tersebut. Sistem ini diharapkan agar untuk selalu di back up secara berkala sehingga dalam penggunaanya dapat terhindar dari virus yang menyebabkan terganggunya sistem atau kehilangan data

\section{DAFTAR PUSTAKA}

[1] Mubarak, S. A. (2015). CONSTRUCTION PROJECT SCHEDULLING AND CONTROL. John Wiley \& Sons.

[2] KBBI (Kamus Besar Bahasa Indonesia), 2015

[3] Nugroho, B. P., \& Jayanti, S. (2017). IMPLEMENTASI SISTEM INFORMASI BERBASIS WEB (Studi Kasus Gereja GKE Sion Palangkaraya). Jurnal Saintekom, $7(2), 138-152$.

[4] TIARA BESTARI, N. A. N. D. A. (2020). RANCANG BANGUN APLIKASI AGENDA RAPAT BERBASIS ANDROID. Jurnal Manajemen Informatika, 10(1).

[5] Alfarisi, S. (2018). SIETEM INFORMASI PENJADWALAN KEGIATAN BELAJAR MENGAJAR PADA MI AL-FALAH BERBASIS ANDROID. PROSIDING SEMNASTEK $2018,1(1)$.

[6] Rahmayunita, A. M., Suryatiningsih, S., \& Telnoni, P. A. (2019). SISTEM INFORMASI RUANG RAPAT (siamir) DI PT PERTAMINA GEOTHERMAL ENERGY WILAYAH KAMOJANG. eProceedings of Applied Science, 5(3).

[7] Subhiyakto, E. R., \& Astuti, Y. P. (2019). PENGEMBANGAN APLIKASI PENJADWALAN RAPAT MENGGUNAKAN METODE PHASED DEVELOPMENT. Jurnal Ilmiah Dinamika Rekayasa, 15(1), 35-46.

[8] Anggraini, W., \& Warman, F. N. (2019). PERBAIKAN BERKELANJUTAN PADA SISTEM PENJADWALAN PERKULIAHAN DENGAN PENJADWALAN BERBASIS APLIKASI DAN WEBSITE. Engineering, MAthematics and Computer Science (EMACS) Journal, 1(1), 11-16. 
ISSN : $2356-5195$

Online ISSN: 2654 - 8704

[9] Hassan, M. A. H., \& Hassan, O. A. H. (2016). CONSTRAINTS AWARE AND USER FRIENDLY EXAM SCHDULLING SYSTEM. Int. Arab J. Inf. Technol., 13(1A), 156-162.

[10] Rohini, V., \& Natarajan, A. M. (2016). COMPARISON OF GENETIC ALGORTHM WITH PARTICLE SWARM OPTIMISATION, ANT COLONY OPTIMISATION AND TABU SEARCH BASED ON UNIVERSITY COURCE SCHEDULLING SYSTEM. Indian Journal of Science and Technology, 9(21), 1-5. 